\title{
Behavior of Foundation Subgrade at Maleo PLTG Tanks Based on CPT Data
}

\author{
Sulha Sulha ${ }^{1}$, Umran Sarita ${ }^{2}$, Lauhil Mahfuz ${ }^{3}$, Try Sugiyarto ${ }^{4}$, Fitriah Fitriah $^{5}$ \\ \{sulha@uho.ac.id ${ }^{1}$, umran.sarita@yahoo.com², mahfuzlauhil015@gmail.com ${ }^{3}$ \} \\ 1,2,3,4,5 Program Pendidikan Vokasi, Jurusan D3 Teknik Sipil, Halu Oleo University, Indonesia
}

\begin{abstract}
The stability of a structure is not only determined by the upper structure which directly bears the burden on the structure, but the stability of the lower structure in this case the foundation and capability of the subgrade support all loads to be very important. Good and accurate soil investigations are needed to calculate soil stability. Adequate soil investigations will not cause the estimated carrying capacity to be too low or high of foundation capacity. Design becomes uneconomical and recommendations given cannot be accepted in the worst conditions and even failures. Recently, one PLTG in Gorontalo was built with one operational support facility in the form of an oil tank. Investigation of soil in the oil tank area shows that the dense layer is at a depth of 2.5 meters below the ground level, and a solid layer is at a depth of 16 meters. This study aims to evaluate the behavior of soils on carrying capacity and permissible decreases of $100 \mathrm{~mm}$. The analysis uses the finite-element method by the help of Plaxis. The analogy approach is done by modeling the structure, foundation and soil coating load based on foundation conditions and CPT data. The results of the analysis show that the carrying capacity of rolling and sliding is quite safe. Decrease in foundation subgrade meets the specified criteria so that the foundation soil is stable enough to support static and dynamic loads.
\end{abstract}

Keywords: Soil Investigation, Foundation, Numerical Analysis, Stability, Settlement.

\section{Introduction}

Each construction project has problems in planning, aswell as construction of foundation son oil tanks. One of the problems facedin the design of oil tank construction is the lack of uniform it your technical guide lines for the design and design patterns that have been set. Oil tank foundation construction will be more reliable if planning analysisis carried out especially the behavior of sub grade under the foundation.

To use the tank safely and effectively for a long time, we must avoid uneven decreases. Tank pressure is concentrated in the bottom of the tank, especially the first and second layers. To over come the failure of this part, we have to pay more expensive, so we need inspection and security analys is work [1]. Kumaretal., 2015 said that numerical modeling of pile foundations efficiently staticand seismic loading condition sand can be used not only for the validation of statically designed models but also be used to obtain responses from foundation systems in various seismic loading conditions [2].

The purpose of this study was to determine the stability of the foundation based on the carrying capacity of the subgrade, rolling force, shear force and foundation reduction using numerical modeling of static and dynamic loads. This research his expected to providean over view of the stability analysis of tank foundations based on sondir sound test results (Dutch Cone Penetrometer) for it. 


\section{Literature Review}

\section{a. Loads}

The calculated plan load is

- Tank loads (LL and DL), namely live loads, wall plate loads, bases, roofs, main pillars, roof truss, nozzles, stairs and hand rails [3].

- Operation loads (OL) namely oil load after filling the tank.

- Windload (WL) which is the load due to wind pressure based on local wind speed[3]. $W_{L}=C_{e} \cdot C_{g} \cdot q_{s} \cdot I_{w}$

Where Ce is combined height, exposure and gust factor coefficient as given in Table 16-G (Eksposur C) [3], Cg is pressure coefficient for the structure or portion of structure under construction as given in Table 16- $\mathrm{H}$ [3], Qs is wind stagnation pressure at standard height of $10000 \mathrm{~mm}$ as forth in Table 16-F [3], Iw is importance factor as set forth in Table 16-K [3].

- $\quad$ Earthquake load (V) which is the maximum earthquake load [3].

$V=\frac{2,5 \cdot C_{a} \cdot I}{R} W$

Where Ca is seismic coefficient, as set forth in Table 16-Q, I is importance factor given in Table 16-K, $\mathrm{R}$ is numerical coefficient representative of the inherent over strength and global ductility capacity of lateral force-resisting systems, as set forth in Table16-N or16-P, W is the total seismic dead load defined in Section 1630.1.1.

\section{b. Bearing capacity of soil}

Soil carrying capacity is the ability of the soil to with stand building pressure or load safely without causing she are share collap seand excessive reduction. The value of carrying capacity of as oil is based on the characteristics of the subgrade. In this study, shear strength parameters were determined based on the correlation of the CPT test results. Soil consistency can be determined based on the relationship between tip resistance and sticking ratio according to figure 1 (Schmertmann, 1978). Estimate value of the frictionangle in the soil based on the consistency of the soil and the end value $q_{c}$ according to the following table.

Table 1. Estimated value of $\phi$ based on soil consistency and value of qc [4].

\begin{tabular}{llcccc}
\hline \multirow{2}{*}{ Description } & $\begin{array}{c}\text { Relative } \\
\text { density, } D_{r}(\%)\end{array}$ & $\begin{array}{c}\text { Cone resistance, } \\
q c(\mathrm{MPa})\end{array}$ & \multirow{2}{*}{$\phi^{\circ}$} & \multicolumn{2}{c}{ Unit weight range $(\mathrm{kPa})$} \\
\cline { 5 - 6 } & $\mathrm{D}_{\mathrm{r}}<15$ & $<2,5$ & $<30$ & Dry & Saturated \\
\hline Very Loose & $2,5-5,0$ & $30-35$ & 14 & 17 \\
Loose & $\mathrm{D}_{\mathrm{r}}=15-35$ & $5,0-10,0$ & $35-40$ & 17 & 18 \\
Med dense & $\mathrm{D}_{\mathrm{r}}=35-65$ & $10,0-20,0$ & $40-45$ & 19 & 20 \\
Dense & $\mathrm{D}_{\mathrm{r}}=65-85$ & $>20.0$ & $>45$ & 21 & 22 \\
Very dense & $\mathrm{D}_{\mathrm{r}}>85$ & &
\end{tabular}




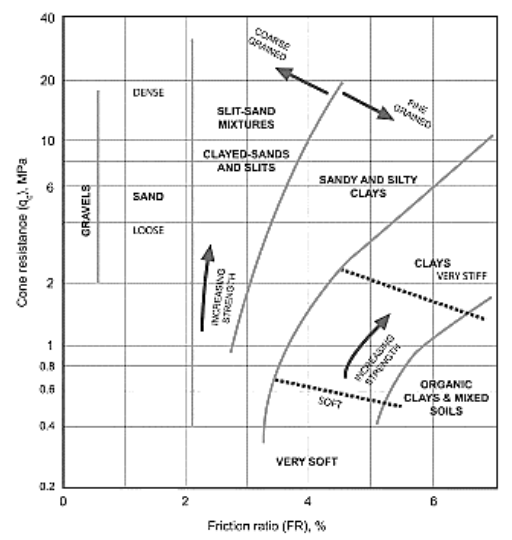

Figure 1. CPT properties, and strength changes for mechanical cones (Schertmann, 1978) [4]

Table 2. Estimated of Young Modulus on type of materials (Gordon, 1978) [4].

\begin{tabular}{llc}
\hline \multicolumn{1}{c}{ Classification } & \multicolumn{1}{c}{ Materials } & $\begin{array}{c}\text { Young Modulus, E } \\
\text { (MPa) }\end{array}$ \\
\hline constructions & Rubber & 7 \\
& Concrete & 20.000 \\
Soils & Soft clays & 5 \\
& Stiff clays, loose sands & 20 \\
\multirow{5}{*}{ Rocks } & Dense sands & 50 \\
& Extremely weathered, soft & 50 \\
& Distinctly weatherd, Soft & 200 \\
& Slightly weathered, fresh, hard & 50.000 \\
\hline
\end{tabular}

Ingeneral, the analysis of the carrying capacity of the land is determined from the ultimate carrying capacity divided by security factors that are appropri ateand carried out by an empirical approach to facilitate calculations. The shallow foundation is determined from $D_{f} \leq$ B, where $D_{f}$ is the depth of foundation, and B are the widthor diameter of the foundation [5]. According to Schertmann (1978) the equality of carrying capacity of land permit sat the base of the foundationis:

$$
\begin{aligned}
q_{\text {all }} & =\left(5+0,34 q_{c}\right) / S F \\
q_{\text {all }} & \geq q_{R}, q_{S} \ldots \ldots \ldots \ldots \ldots \\
q_{R} & =\mathrm{N}_{\mathrm{R}} / \mathrm{AF}+\mathrm{M}_{\mathrm{O}} / \mathrm{mF} \\
q_{S} & =\mathrm{N}_{\mathrm{S}} / \mathrm{A}_{\mathrm{S}} \ldots \ldots \ldots \ldots
\end{aligned}
$$

where $q_{\text {all }}$ is allow able of bearing capacity $\left(\mathrm{kg} / \mathrm{cm}^{2}\right), q_{c}$ is cone resistance $\left(\mathrm{kg} / \mathrm{cm}^{2}\right), q_{R}$ is maximum soil pressure below ring $\left(\mathrm{kg} / \mathrm{cm}^{2}\right), \mathrm{N}_{\mathrm{R}}$ is vertical load at below ring $(\mathrm{kg}), \mathrm{A}_{\mathrm{F}}$ is Area of ring foundation $(\mathrm{cm} 2)$, Mo is moment due to wind and seismic load $(\mathrm{kg} . \mathrm{cm}), \mathrm{m}_{\mathrm{F}}$ is section modulus of ring foundation $\left(\mathrm{cm}^{3}\right), q_{s}$ is maximum soil pressure below soil $\left(\mathrm{kg} / \mathrm{cm}^{2}\right)$, Ns is vertical load at below soil $(\mathrm{kg})$, As is area of soil $\left(\mathrm{cm}^{2}\right)$. 
According to Reese and O' Neill, 1989 suggested the selection of safety factors (SF) for foundation design taking into account the contro lfactors of work implementation. The range of SF that are often used is around 2-4, and most are used 3.

\section{c. Moment Stability}

Pressure oneach side causes the building to tend to rotate on the foot building $\left(M_{R}\right)$, while the vertical pressure on the building and ground pressure, on the other hand, reduces the moment $\left(M_{0}\right)$.The safe factor for rolling $\left(F_{0}\right)$ is 1.5 [3] definedas follows:

$$
F_{0}=\frac{M_{R}}{M_{0}} \geq 1,5
$$

Where:

$F_{0}$ is safe factor for over turning, $M_{R}$ is moment of resistance against over turning (kN.m), $M_{0}$ is the moment that caused the over turning $(\mathrm{kN} . \mathrm{m}), 1,5$ is safety factor for granular subgrade

\section{d. Shear Stability}

The forces that shift the construction will be held back by the weight of the construction and the friction between the soil and the foundation of the foundation. As are factor against. Bowles' minimum foundation base shift,1997 suggested 1.5 [7]. SF for shifting is defined as follows.

$$
F_{s}=\frac{H_{R}}{H} \geq 1,5
$$

where:

$F_{s}$ is safe factor for shear on base of foundation, $H_{R}$ is foundation resistance to shift $(\mathrm{kN})$, $\mathrm{Hi}$ s numbers of horizontal forces $(\mathrm{kN}), 1,5$ is safety factor for granular subgrade

\section{e. Settlement}

The problem of decreasing the foundation becomes very importants if there is asettlement in difference between the two adjacent foundation points, this causing angular distortion $(\delta / \mathrm{L})$. The total reduction foundation in $5-10 \mathrm{~cm}$ and non-uniform decrease is 0.005 $\mathrm{L}$ according to table 3 .

Table 3. Allowable settlement (Sowers, 1962) [7]

\begin{tabular}{clc}
\hline $\begin{array}{c}\text { Type of } \\
\text { movement }\end{array}$ & \multicolumn{1}{c}{ Limiting factor } & Maximum settlement $(\mathrm{cm})$ \\
\hline Total settlement & Drainage & $15-30$ \\
& Access & $30-60$ \\
& Probability of nonuniform settlement: & \\
& $\quad$ Masonry walled structure & $2,5-5$ \\
& $\quad$ Framed structure & $5-10$ \\
& $\quad$ Smokestacks, silos, mats & $8-30$ \\
\hline Differential & High continuous brick walls & $(0,0005-0,001) \mathrm{L}$ \\
movement & One-story brick mill building, wall & $(0,001-0,002) \mathrm{L}$ \\
& cracking & $0,001 \mathrm{~L}$ \\
& Plaster cracking (gypsum) & $(0,0025-0,004) \mathrm{L}$ \\
\hline
\end{tabular}




$\begin{array}{ll}\text { Reinforced-concrete building frame } & 0,003 \mathrm{~L} \\ \text { Reinforced-concrete building curtain } & 0,002 \mathrm{~L} \\ \text { walls } & 0,005 \mathrm{~L}\end{array}$

walls

$0,005 \mathrm{~L}$

Steel frame, continuous

Simple steel frame

\section{Research method}

\subsection{Soil conditions}

At this stage, data collection on soil testing results was carried out on the Maleo PLTG Tank Construction Project in Paguat District, Pohuwatu Regency, Gorontalo Province Indonesia according to the location map in figure 3. Soil testing data in the field with DCPT/ Sondir are three points with hard soil depth of $\mathrm{q}_{\mathrm{c}}>150 \mathrm{~kg} / \mathrm{cm} 2$ [5] which are $\pm 16 \mathrm{~m}$. The results of analysis of test data are made in the graphical form. Referring to the 2017 earthquake map of Indonesia with aprobability of exceeding $10 \%$ in 50 years, this region is in a zone with an earthquake acceleration coefficient of $0.30 \mathrm{~g}$. $-0.40 \mathrm{~g}$. Plaxis analysis by using dynamic loads in the formof time history of earthquakes [8].

\subsection{Structure and loading construction}

At this stage, the research is carried out by calculating the construction load based on the planning drawing, and earthquake load used in the peak acceleration map in bedrock for a probability exceeding $10 \%$ in 50 years [9]. Wind load based on wind velocity by month in Gorontalo Province [10]. The calculated plan load is dead load (DL), Operational Load (OL), windload (WL) and earthquake load (EL). The combination of loading refers to the LRFD without the loading factor coefficient.

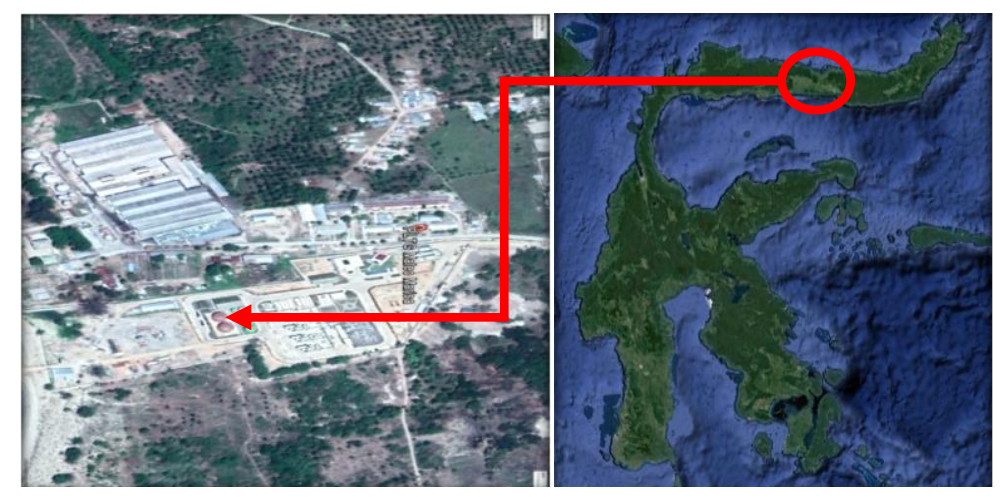

Figure 2. Study location [11].

\subsection{Modelling and Analysis of Foundation Stability}

At this stage, the calculation of the foundation stability analysis of the carrying capacity of the soil, sliding and rolling is calculated based on a combination of loading and specified safety factors. Furthermore, structure and loading modeling are carried out in Plaxis to analyze the decline that occurs due to the applied load. The earthquake load used in the analysis is 350 $\mathrm{cm} / \mathrm{s}^{2}$ according to figure 7 . The research stages are presented in the following figure. 


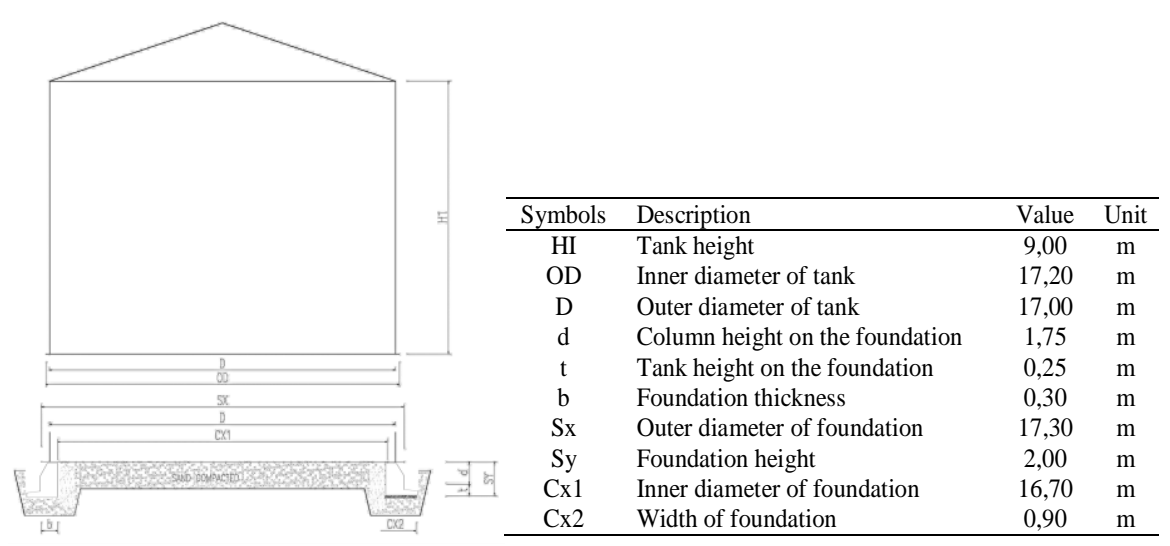

Figure 3. Foundation and tank dimentions [12]

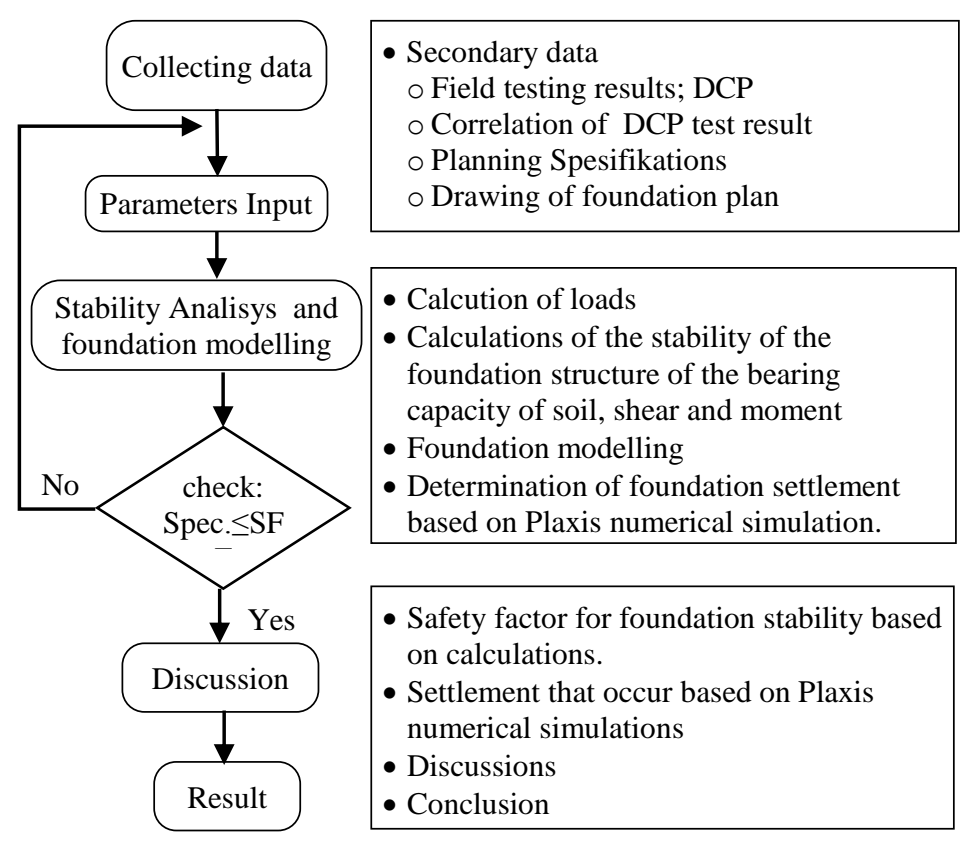

Figure 4. Research flow chart

The foundation of the tank is circular so that finite-element modeling is axisymetric according to figure 6 . Earthquake against the foundation is in the formof inputting time history plaxis the $2 \mathrm{D}$ plaxis program. 


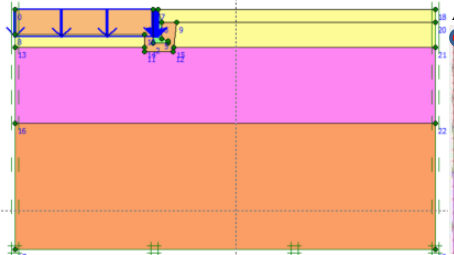

(a)

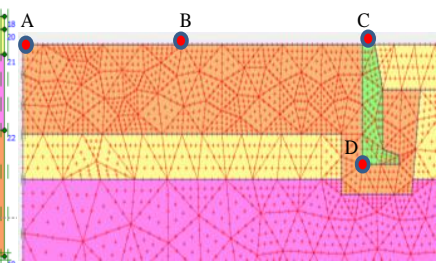

(b)

Figure 5. (a) Modeling existing foundation conditions, (b) stress observation and settlement points.

\section{Result and discussions}

\subsection{Soil, steel and concrete properties}

From the results of the CPT test, acorrelation was made with respect to soil shear strength. As for other materials, can be seen in the following table.

Table 4. Materials data as input

\begin{tabular}{|c|c|c|c|c|c|}
\hline Parameters & Name & Clay & Sand & Deep Sand & Unit \\
\hline Soil layers $(\mathrm{m})$ & & $0-2$ & $2-6$ & $6-12$ & \\
\hline Material model & - & Mohr Coulomb & Mohr Coulomb & Mohr Coulomb & - \\
\hline Type of material behaviour & - & Drained & Drained & Drained & - \\
\hline Soil unit weight above phreatic level & $\gamma_{\text {unsat }}$ & 15,5 & 16,5 & 17 & $\mathrm{kN} / \mathrm{m}^{3}$ \\
\hline Soil unit weight below phreatic level & $\gamma_{\mathrm{sat}}$ & 18 & 20 & 21 & $\mathrm{kN} / \mathrm{m}^{3}$ \\
\hline Permeabilityin horizontal direction & $\mathrm{k}_{\mathrm{x}}$ & 0,0001 & & & $\mathrm{~m} / \mathrm{det}$ \\
\hline Permeabilityin vertical direction & $\mathrm{k}_{\mathrm{y}}$ & 0,0001 & & & $\mathrm{~m} / \mathrm{det}$ \\
\hline Young modulus & $\mathrm{E}_{\mathrm{ref}}$ & 9700 & 98000 & 120000 & $\mathrm{kN} / \mathrm{m}^{2}$ \\
\hline Poisson's ratio & $v$ & 0,2 & 0,2 & 0,2 & - \\
\hline Cohesssion & $c_{\text {ref }}$ & 5,5 & 1 & 1 & $\mathrm{kN} / \mathrm{m}^{2}$ \\
\hline Friction angle & $\varphi$ & 24 & 31 & 33 & 0 \\
\hline Dynamic friction angle $(\varphi-2)^{0}$ & $\varphi_{\text {din }}$ & 22 & 29 & 31 & 0 \\
\hline Dilatancy angle & $\psi$ & 0 & 1 & 3 & 0 \\
\hline Strength reduction factor inter & $\mathrm{R}_{\text {inter }}$ & rigid & rigid & 0,75 & - \\
\hline \multicolumn{6}{|c|}{ Foundation } \\
\hline Material model & - & Linier Elastic & & & - \\
\hline Type of material behaviour & - & Non porous & & & - \\
\hline Concrete unit weight & $\gamma_{\text {conc. }}$ & 24 & & & $\mathrm{kN} / \mathrm{m}^{3}$ \\
\hline Young modulus & $\mathrm{E}_{\mathrm{ref}}$ & 30.000 .000 & & & $\mathrm{kN} / \mathrm{m}^{2}$ \\
\hline Poisson's ratio & $v$ & 0,2 & & & - \\
\hline
\end{tabular}




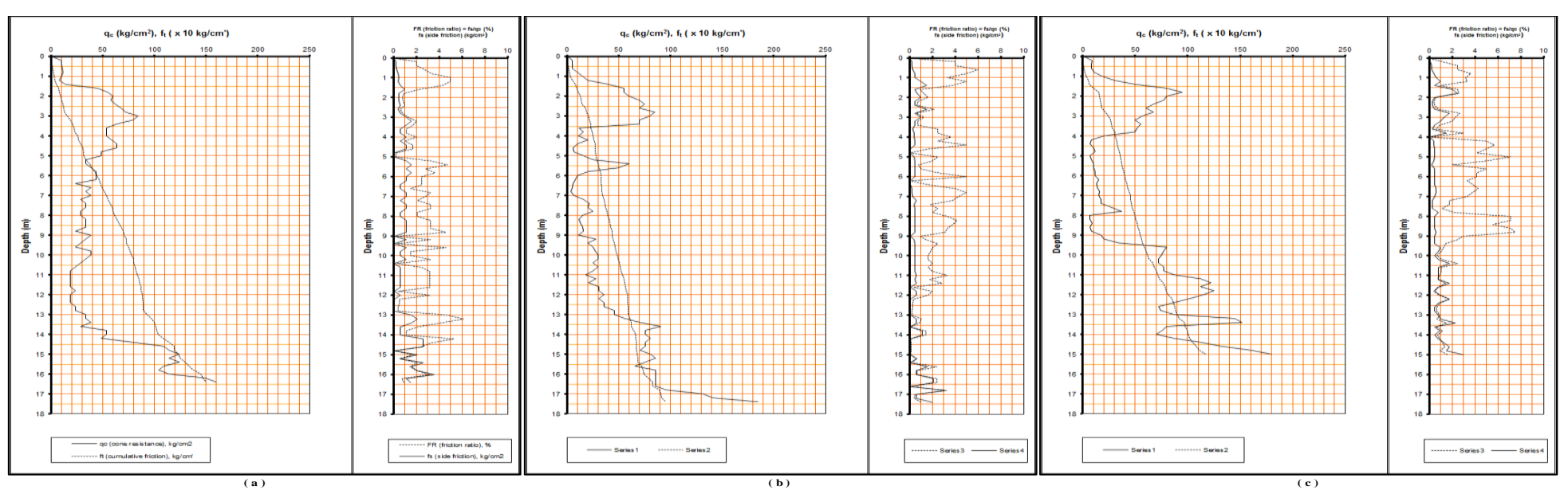

Figure 6.Data from DCP testing results(a) SO-01, (b) SO-02 dan (c) SO-03 [12]

Table 5. Average value of $\overline{q c}$ and $\overline{F R}$

\begin{tabular}{|c|c|c|c|c|c|c|c|c|c|}
\hline \multirow[b]{2}{*}{$\begin{array}{l}\text { Depth } \\
\text { (m) }\end{array}$} & \multicolumn{3}{|c|}{$\mathrm{SO}-1$} & \multicolumn{3}{|c|}{ SO - 2} & \multicolumn{2}{|c|}{$\mathrm{SO}-3$} & \multirow[b]{2}{*}{$\overline{F R}$} \\
\hline & $\begin{array}{c}\mathrm{qc} \\
\left(\mathrm{kg} / \mathrm{cm}^{2}\right)\end{array}$ & $\begin{array}{c}\overline{q c} \\
\left(\mathrm{~kg} / \mathrm{cm}^{2}\right)\end{array}$ & $\overline{F R}$ & $\begin{array}{c}\mathrm{qc} \\
\left(\mathrm{kg} / \mathrm{cm}^{2}\right)\end{array}$ & $\begin{array}{c}\overline{q c} \\
\left(\mathrm{~kg} / \mathrm{cm}^{2}\right)\end{array}$ & $\overline{F R}$ & $\begin{array}{c}\mathrm{qc} \\
\left(\mathrm{kg} / \mathrm{cm}^{2}\right. \\
)\end{array}$ & $\begin{array}{c}\overline{q c} \\
\left(\mathrm{~kg} / \mathrm{cm}^{2}\right)\end{array}$ & \\
\hline 1,20 & 8 & & & 20 & & & 30 & & \\
\hline 1,40 & 14 & & & 40 & & & 50 & & \\
\hline 1,60 & 45 & 36 & 2,5 & 55 & 46 & 3 & 80 & 67 & 1,5 \\
\hline 1,80 & 55 & & & 55 & & & 95 & & \\
\hline 2,00 & 60 & & & 60 & & & 80 & & \\
\hline
\end{tabular}

Table 6. Wind velocity by month in Gorontalo Province, Pohuwatu Regency in Figures, 2017 Manuary

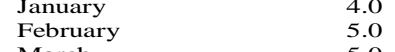

February

March

April
May
June
July

July

September

October

December

Based on the table above, the maximum wind speed occurs in February and March which is 5 knots or $10 \mathrm{Km} / \mathrm{hour}$. 


\section{a. Foundation Stability}

Calculation of the stability in this case is allow able bearing capacity $\left(q_{\text {all }}\right)$ of soil based on soil testing sondir. The average $q_{c}$ value used in the calculation is $36 \mathrm{~kg} / \mathrm{cm} 2$ with $\mathrm{SF}=3$. In this analysis, the $q_{\text {all }}$ factor coefficient is not taken $q_{\text {all }}$ account. It calculations according to Schmertmann (1978) areas follows:

$q_{\text {all }}=(5+0,34 * 36) / 3=5,75 \mathrm{~kg} / \mathrm{cm}^{2}$

Table 6. Recapitultion of calculation foundation load.

\begin{tabular}{cccccc}
\hline \multirow{2}{*}{ Load } & \multirow{2}{*}{ Remarks } & \multicolumn{2}{c}{ Vertical $(\mathrm{kg})$} & Horisontal $(\mathrm{kg})$ & Moment $(\mathrm{kg} . \mathrm{cm})$ \\
\cline { 3 - 6 } & & Below Ring $\left(\mathrm{N}_{\mathrm{R}}\right)$ & Below Soil $\left(\mathrm{N}_{\mathrm{S}}\right)$ & $\mathrm{H}$ & Mo \\
\hline \multirow{2}{*}{$\mathrm{D}_{\mathrm{L}}$} & Equip Erecting & $128.430,06$ & - & - & - \\
& $\mathrm{W}_{\mathrm{O}}$ & $56.045,16$ & $1.546 .037,05$ & - & - \\
$\mathrm{OL}$ & $\mathrm{L}_{\mathrm{L}}$ & $6.675,884$ & - & - & - \\
& $\mathrm{W}_{\mathrm{O}}+\mathrm{L}_{\mathrm{L}}$ & $62.721,04$ & $1.546 .037,05$ & - & - \\
$\mathrm{Ww}$ & Wind Load & $3.244,21$ & - & $10.788,073$ & $4.854 .632,866$ \\
$\mathrm{EL}$ & $\mathrm{V}$ & $87.024,25$ & - & $355.909,849$ & $160.159 .431,895$ \\
\hline
\end{tabular}

Table 7. Calculation of soil bearing capacity.

\begin{tabular}{|c|c|c|c|c|c|c|}
\hline \multirow{2}{*}{ Loads combination } & \multicolumn{5}{|c|}{$q\left(\mathrm{~kg} / \mathrm{cm}^{2}\right)$} & \multirow{2}{*}{$\begin{array}{c}\text { Result } \\
\left(q_{S} \text { and } q_{R}<q_{\text {All }}\right)\end{array}$} \\
\hline & $\mathrm{N}_{\mathrm{R}} / \mathrm{A}_{\mathrm{F}}$ & $\mathrm{M}_{\mathrm{O}} / \mathrm{m}_{\mathrm{F}}$ & $q_{R}$ & $q_{S}$ & $q_{\text {All }}$ & \\
\hline$\overline{\mathrm{DL}}$ & 0,802 & 0,000 & 0,802 & 0,000 & 5,75 & $\overline{\text { safe }}$ \\
\hline $\mathrm{DL}+\mathrm{OL}$ & 1,151 & 0,000 & 1,151 & 0,71 & 5,75 & safe \\
\hline $\mathrm{DL}+\mathrm{Ww}+\mathrm{OL}$ & 1,184 & 0,152 & 1,336 & 0,706 & 5,75 & safe \\
\hline $\mathrm{DL}+\mathrm{EL}+\mathrm{OL}$ & 1,695 & 3,136 & 4,830 & 0,706 & 5,75 & safe \\
\hline $\mathrm{DL}-\mathrm{EL}+\mathrm{OL}$ & 0,608 & $-3,136$ & $-2,527$ & 0,706 & 5,75 & safe \\
\hline $\mathrm{DL}+\mathrm{EL}$ & 1,345 & 3,136 & 4,480 & 0,000 & 5,75 & safe \\
\hline DL - EL & 0,258 & $-3,136$ & $-2,877$ & 0,000 & 5,75 & safe \\
\hline
\end{tabular}

\section{b. Safety factor and Settlement foundation.}

From Table 8 above, it can be seen the value of safety a factor used by 3 . It is indicated that the foundation stability shows the foundation allowable stress is not exceeded so that the foundation is quite stable. This is due to a fairly wide foundation, so that the stress that occurs is relatively small. The results of the plaxis analysis show that the maximum stress that occurs at the base of the foundation is $1,05 \mathrm{Kg} / \mathrm{cm}^{2}$.

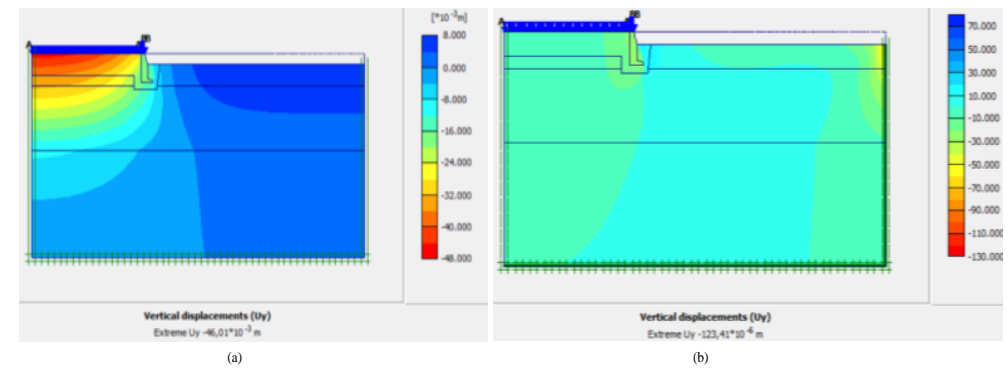

Figure 7. Settlement that occur (a) due to axial loads, (b) due to axial and earthquake loads. 
Based plaxis analysis, it shows that the total settlement that occurred during the earthquake than acceleration of $350 \mathrm{~cm} / \mathrm{s}^{2}$ was $0.024 \mathrm{~cm}$. There are 4 points reviewed, namely at the bottom of the tank (point A, B, C) and the foundation base (point D) as shown in figure 10. In this analysis, the load combination does not use a load factor, but in the calculation control using the recommended safe factor. This is more efficient in accordance with the load that works and there is no excessive loading.

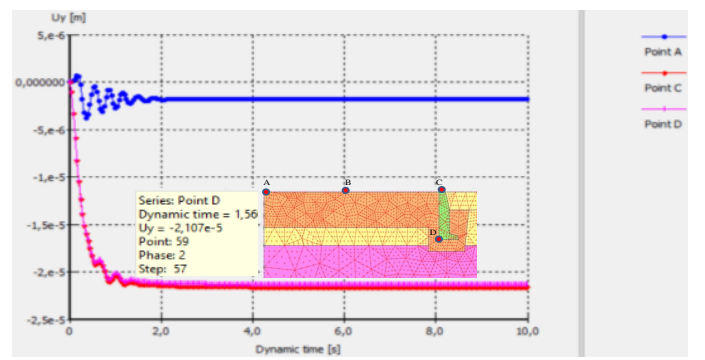

Figure 8. Vertical displacement-time curves at the base due to earthquake loads.

\section{Conclusion}

Complete and accurate soil investigation is needed for planning the foundation structure. Soil bearing capacity, shear stress, moment and settlement that occur assuming the foundation within the recommended tolerance limit. In general, the foundation used in this analysis is quites table in carrying the load plan both statically and dynamically.

\section{References}

[1] GONG Ke \& and J.-S. HU, "Large Storage Tanks Foundation Settlement Structural MechanicsCharacteristics Analysis,” DEStech Trans. Mater. Sci. Eng., no. icmsea/mce, pp. 1-7, 2018.

[2] K. Ashutosh, C. Deepankar, S. Jaykumar, and D. L. Shah, "Seismic Design of Pile Foundation for Oil Tank by using PLAXIS3D,” Disaster Adv., vol. 8, no. 6, pp. 33-42, 2015.

[3] API650, Welded storage tanks for oil storage, API 650. American Petroleum Institute Standard, vol. 552, no. 3. Washington, D.C.: API, 2005.

[4] B. Look, Handbook of Geotechnical Investigation and Design Tables. London, UK: Taylor \& Francis/Balkema, 2007.

[5] K. Terzaghi, Theoretical Soil Mechanics. New York: John Wiley \& Sons, 1943.

[6] J. E. Bowles, Foundation Analysis and Design. United States: McGraw-Hill Companies, 1977.

[7] R. W. Day, Foundation Eninnering 2009 International Building Code, Second. New York: Mc Graw Will, 2009.

[8] R. B. J. \& B. W. Brinkgreve, Tutorial Manual Plaxis 2D, Version 8. Netherlands: A.A.Balkema, 2002.

[9] Tim Pusat Studi Gempa, Peta Sumber dan Bahaya Gempa Indonesia Tahun 2017, 2017.

[10] BPS-Pohuwatu, Kabupaten Pohuwatu Dalam Angka 2017. Gorontalo: BPS-Pohuwatu, 2017.

[11] Google Inc., "Google Earth Pro," [Online]. Available: https://www.google.com. 
[Accessed: 23-Mar-2019], 2019.

[12] PT. Anugrah Teknik Mandiri, "Penyelidikan tanah dan Pondasi PLTG Maleo," Gorontalo, 2017. 